KAMIL JAWORSKI

Kancelaria Prezesa Rady Ministrów

ORCID: 0000-0001-8171-5961

e-mail: kamil_jaworski@wp.pl

\title{
Manifest realizmu w XXI wieku?
}

Recenzja książki Anatola Lievena pod tytułem Climate change and the Nation State

\section{A manifesto of realism in the $21^{15}$ century?}

A review of the book entitled 'Climate change and the Nation State' by Anatol Lieven 

fy bardziej rozległa* i silniejsza rola instytucji międzynarodowych i ponadnarodowych organów jest szansą na większą skuteczność w walce ze zmianami klimatu? Czy problematyka klimatyczna powinna być domeną jedynie lewicy, ekologów i krytyków wolnorynkowego kapitalizmu? Czy tym, czego najbardziej powinniśmy się obawiać jest ryzyko nowej zimnej wojny między Stanami Zjednoczonymi a Chinami? Jakie znaczenie ma demokratyczny lub autorytarny ustrój polityczny w skuteczności walki ze zmianami klimatu? Dlaczego problematyka zmian klimatu powinna być w samym centrum uwagi szkoły realistycznej w ramach teorii stosunków międzynarodowych? No i wreszcie dlaczego podejście do problemu migracji ma tak kluczowe znaczenie w kontekście skuteczności działań w dziedzinie zmian klimatu podejmowanych w zachodnich społeczeństwach? Każdy, kto uznaje te pytania za intrygujące i ważne, powinien sięgnąć po lekturę najnowszej książki Anatola Lievena ${ }^{1}$.

Ten były korespondent brytyjskich mediów kolejno w Pakistanie, Indiach oraz Czechosłowacji i Rumunii w czasie przełomu ustrojowego, zajmujący się problematyką państw byłego ZSRS, z czasem zamienił swoją profesję dziennikarza na karierę akademicką. Związany jest przede wszystkim z King's College w Londynie oraz filią Georgetown University w Katarze. Jego zainteresowania badawcze koncentrują się na ocenie roli Stanów Zjednoczonych w świecie oraz na zagadnieniu terroryzmu i sytuacji politycznej w państwach, z którymi miał styczność w czasie swojej kariery dziennikarskiej, czyli w Pakistanie, Afganistanie i krajach tworzących niegdyś wspólny obóz pod dominacją zSRS. Życiowe doświadczenia Lievena są jednak szczególnie ważne w kontekście tego, co ma on do powiedzenia w kwestii znaczenia idei narodowej, patriotyzmu czy roli państwa narodowego we współczesnym świecie. Predestynują go one bowiem do zajmowania stanowiska nie tylko z perspektywy reprezentanta świata zachodniego, ale też naocznego obserwatora problemów państwowości na Bliskim i Środkowym Wschodzie lub południowej Azji oraz przechodzących transformację ustrojową państw Europy Środkowej i Wschodniej, a także byłego ZSRS.

Ów rys dziennikarskich doświadczeń oraz zainteresowań badawczych sprawia, że sięgając po nomen omen gorący temat, jakim jest problem zmian

* $\quad$ Artykuł odzwierciedla poglądy autora, a nie instytucji, w której pracuje.

1 A. Lieven, Climate Change and the Nation State. The Realist Case, Allen Lane, London 2020, ss. 240. 
klimatu, Lieven przedstawił go w nowym ujęciu, kwestionując niektóre dotychczasowe założenia i poglądy funkcjonujące na gruncie istniejących podziałów politycznych czy też na płaszczyźnie akademickiej wśród badaczy stosunków międzynarodowych. Zaproponowane przez brytyjskiego autora ujęcie może nie być w smak sympatykom środowisk lewicowo-liberalnych. Staje ono też niekiedy na przekór wizji świata, którą pielęgnują konserwatyści. Choć wątek Polski w książce właściwie się nie pojawia ${ }^{2}$, to również u części czytelników w naszym kraju może ona wywołać zaniepokojenie, a na pewno powinna co najmniej skłonić do szerszych refleksji. Prezentowana książka jest nade wszystko doniosłym apelem o docenienie roli państwa narodowego i potrzeby renesansu obywatelskiego patriotyzmu w ramach szerokiego konsensusu społecznego, niezbędnego, aby móc skutecznie stawić czoło globalnemu wyzwaniu, jakim są zmiany klimatyczne.

Ta około dwustustronicowa książka została wydana w 2020 roku. Składa się ze wstępu, pięciu rozdziałów i konkluzji. To nie tyle pogłębiona i obszerna monografia, co rzeczowy i polemiczny tekst, którego celem jest zabranie głosu w kluczowych sprawach współczesnego świata. Punktem wyjścia dla rozważań Lievena jest jego przeświadczenie o fundamentalnym znaczeniu zagrożeń wynikających ze zmian klimatu dla bezpieczeństwa państw oraz dla ich przyszłej sytuacji wewnętrznej, jak i szeroko rozumianej polityki międzynarodowej. Autor, określając się mianem realisty inspirującego się myślą takich postaci jak Reinhold Niebuhr, Hans Morgenthau czy George Kennan, nawołuje współczesnych przedstawicieli szkoły realistycznej do ocknięcia się i przyznania problematyce klimatycznej właściwego, jego zdaniem, czyli centralnego znaczenia. Formułuje przy tym jednoznacznie tezę mówiącą, że długoterminowe interesy światowych mocarstw są bardziej zagrożone zmianami klimatu niż ich ewentualnymi wzajemnymi konfliktami. Współczesny realizm, stawiający tradycyjnie w centrum swojego zainteresowania państwo narodowe i jego interesy ${ }^{3}$, powinien więc

2 Polska pojawia się w kontekście przywoływanego tekstu Anne Applebaum, w którym opisuje ona postawę anonimowej zwolenniczki Prawa i Sprawiedliwości. Zob.: A. Lieven, Climate change and the Nation State, Allen Lane, London 2020, s. 75.

3 Istnieje, rzecz jasna, wiele nurtów szkoły realistycznej, w ramach których punkt ciężkości teoretycznych ujęć kładziony jest także na zagadnienia anarchii, bezpieczeństwa, suwerenności czy potęgi. Niezależnie od tego większość rozważań realistów (w tym reprezentantów realizmu klasycznego takich jak R. Niebuhr lub 
dostrzec, że najważniejsze zagrożenia dla bezpieczeństwa narodowego wynikają ze zmian klimatu. Realiści powinni zatem uwzględnić kluczową, zdaniem Lievena, zależność między siłą państw i zdolnością ich przetrwania a skutecznością walki ze zmianami klimatu. Są one bowiem naczyniami połączonymi. Proponuje przy tym modyfikację sloganu ekologów: „Myśl globalnie, działaj lokalnie” na "Myśl globalnie, działaj narodowo”. Wyczekiwanie i postulowanie końca państw narodowych jest jego zdaniem nie tylko bezsensowne, a wręcz groźne dla skuteczności walki ze zmianami klimatu w skali globalnej. Wraz z piętrzącymi się wyzwaniami klimatycznymi upadek państw przyczyniłby się w opinii Lievena prędzej do powszechnego chaosu niż do wyłonienia się jakiejś formy światowego rządu.

W rozdziale pierwszym autor przedstawia zmiany klimatu jako egzystencjalne zagrożenie dla istnienia państwa narodowego. Prawdziwe znaczenie tego problemu wynika zaś z faktu, że ma on mniejsze lub większe oddziaływanie na wiele sfer życia społecznego, co w konsekwencji będzie skutkowało intensyfikacją wielu innych problemów politycznych, gospodarczych czy zdrowotnych. Badacz dostrzega więc potrzebę większego uwzględniania czynnika militarnego $\mathrm{w}$ aktualnie rozważanej problematyce klimatycznej. Wynika to przede wszystkim z jego oceny, że w większości państw świata to właśnie wojskowi reprezentują najwłaściwszą instytucję mogącą zapewnić narodową mobilizację do działań w sprawach związanych ze zmianami klimatu. Ich głos jest ważny przede wszystkim z dwóch względów. Po pierwsze dlatego, że może pomóc dokooptować większą liczbę ludzi o poglądach konserwatywnych i prawicowych do tego rodzaju działalności. Po drugie establishment militarny operuje nie w kategoriach pewników czy hipotez (jak nauka), lecz ryzyk. Wojskowi w swoich działaniach muszą zakładać i przewidywać scenariusze najgorsze. Postuluje on więc, aby analizę ryzyka, wynikającego ze zmian klimatu, postrzegać w sposób taki jak zwykli to robić nie ekonomiści (zanurzeni w teraźniejszości i pogrążeni w osiąganiu krótkoterminowych celów i zysków), lecz generałowie. Formułując swój postulat, Lieven nie szczędzi jednak krytyki amerykańskiemu establishmentowi militarnemu, który często wspiera narrację, zgodnie z którą centralne znaczenie ma odradzająca się nowa forma zimnej wojny i ideologiczna walka między zachodnimi

H. Morgenthau) w bezpośredni lub pośredni sposób koncentruje się wokół tego, co determinuje stosunki polityczne między państwami. 
demokracjami a autorytarnymi mocarstwami, uosabianymi przede wszystkim przez Chiny i Rosję. Brytyjski autor zarzuca wręcz w tym kontekście wielu zachodnim ekspertom do spraw bezpieczeństwa, że pochłaniają ich drugorzędne w istocie zagrożenia wywoływane chińską lub rosyjską obecnością militarną $\mathrm{w}$ niektórych regionach. Tkwią oni bowiem nieustannie $w$ modelach bezpieczeństwa wypracowanych w czasach zimnej wojny. Takie postawienie kwestii bezpieczeństwa może spotkać się z oczywistym niezrozumieniem w państwach Europy Środkowej i Wschodniej czy byłych republikach sowieckich. Każe też postawić pytanie, w jakim stopniu postulaty łączenia problematyki klimatycznej z kwestiami bezpieczeństwa narodowego i międzynarodowego powinny uzyskiwać priorytet, a w jakim jedynie wspierać i uzupełniać już istniejące strategie i plany operacyjne, bez deprecjonowania znaczenia kluczowych dla wybranych państw zagrożeń regionalnych. Uczony zdaje się tu bagatelizować ryzyka odwrócenia priorytetów w polityce bezpieczeństwa dla egzystencji i spójności terytorialnej niektórych państw ${ }^{4}$. Jeśli nawet uznamy zagrożenia klimatyczne za pierwszorzędny problem $\mathrm{w}$ sferze bezpieczeństwa, to pozostanie ono z nami na całe dekady, nie usuwając samoistnie innych problemów międzynarodowych. Można więc chyba pozwolić sobie na metaforę, że Lieven wciela się w lekarza-specjalistę oferującego fachowe leczenie pacjentowi na jego podstawową chorobę przewlekłą, ale niedostrzegającego, że pracuje on w określonych, szkodliwych warunkach, które mogą sprawić, iż pewnego dnia dozna poważnych konsekwencji zdrowotnych właśnie z ich przyczyny, a nie z powodu choroby na którą cierpi.

W rozdziale drugim brytyjski badacz przechodzi do omówienia zasadniczej jego zdaniem interakcji między problemem zmian klimatu z jednej strony a migracją, automatyzacją i rozwojem sztucznej inteligencji - z drugiej. To, że wskazuje on na zależności między skutkami zmian klimatu i wzrostem ryzyka presji migracyjnej na państwa zachodnie, nie jest ani tezą odkrywczą, ani błędną. Bardzo otwarcie krytykuje przy tym postawę wielu zachodnich sił politycznych głównego nurtu - zarówno

4 Warto w tym kontekście przywołać opinię autora, który na samym końcu książki stwierdza, że terytorialne dysputy jak te na Krymie i Morzu Południowochińskim powinny być traktowane jak wiele innych postimperialnych sporów terytorialnych i należy je relegować do pomniejszego znaczenia w ramach szerszego systemu zachodnich interesów narodowych. 
z lewicy, jak i centroprawicy - za bagatelizowanie społecznych obaw przed rosnącą migracją. Autor uważa, że jedną z konsekwencji takiej bezrefleksyjnej postawy był wzrost poparcia dla populistycznej prawicy w wielu krajach. Słusznie konstatuje też, że niedocenienie społecznych obaw przed migracją stało się jedną z ważnych sił napędowych kampanii prezydenta Donalda Trumpa oraz zwolenników wyjścia Zjednoczonego Królestwa z Unii Europejskiej. Istotne w rozważaniach Lievena jest uwypuklane przez niego sprzężenie zwrotne między zmianami klimatu, które z jednej strony potęgują presję migracyjną, a z drugiej - rosnąca migracja podkopuje polityczną jedność państw zachodnich mającą kluczowe znaczenie dla prowadzenia przez nie skutecznej polityki klimatycznej, wymagającej wielu poświęceń ze strony ich społeczeństw. Co więcej, na tak zarysowaną zależność nakłada on wyzwania związane z postępującą automatyzacją i rozwojem sztucznej inteligencji. Mogą one bowiem w przyszłości coraz mocniej kwestionować ekonomiczny sens napływu taniej i niewykwalifikowanej siły roboczej do państw wysoko rozwiniętych. Stawienie czoła tym wyzwaniom wymagać będzie z kolei, według Lievena, znacznej interwencji państwa. Najważniejsze zagrożenie, które widzi w nakładaniu się wyzwań klimatycznych z migracyjnymi i technologicznymi, polega na pogłębianiu różnic między państwami Zachodu i w ostateczności na upadku demokracji.

Trzeci rozdział Lieven poświęcił znaczeniu państwa narodowego w zapewnianiu postępu i przezwyciężaniu kryzysów. Autor daje się tu poznać jako surowy krytyk wszystkich opinii nawołujących do odesłania państwa narodowego do lamusa historii. Choć nie przyznaje tego otwarcie, to zdaje się tę kwestię oceniać jako swoistą "chorobę” Zachodu, który nie rozumie, że w wielu regionach świata jednym z głównych problemów stała się słabość państw. Stwierdza też jasno, że przywiązanie do państwa narodowego w XXI w. nie jest czymś złym, a w odpowiedniej formie może być wręcz czymś pożądanym. W kontekście problematyki klimatycznej wynika to z faktu, że tylko państwo narodowe ma, według Lievena, niezbędną legitymację, by skłaniać swoich obywateli do wyrzeczeń i ponoszenia większych kosztów polityki klimatycznej. W związku z tym otwarcie wskazuje, że w UE taką legitymacją nadal dysponują jedynie jej państwa członkowskie. Posuwa się też do stwierdzenia, że jak ideologia komunistyczna koegzystuje w Chinach z nacjonalizmem, tak demokracja zachodnia przetrwa, gdy zastąpi liberalizm bardziej narodowym podejściem. Współczesnym 
liberalnym reformatorom w UE zarzuca, że podobnie jak dziewiętnastowiecznym liberałom nie brakuje im elitaryzmu, a nawet dozy autorytaryzmu, lecz zapomnieli oni o kluczowym znaczeniu czynnika narodowego patriotyzmu. Interesujące jest też spostrzeżenie badacza, który widzi zasadniczą paralelę między narodowym i ekologicznym punktem widzenia. Jest nią, według niego, ich zdolność do kształtowania postawy wyrzeczeń przez żyjące pokolenia na rzecz przyszłych generacji. Daje się jednocześnie poznać jako krytyk koncentracji polityki w wymiarze ekonomicznym. Tę część książki puentuje konstatacją, zgodnie z którą budowa jedności społeczeństw zachodnich uwarunkowana jest zdolnością konserwatystów do bycia mniej etnicznymi patriotami oraz zdolnością liberałów do bycia większymi obywatelskimi patriotami. Ideę globalnej obywatelskości uważa zaś za wręcz szkodliwą iluzję.

W czwartym rozdziale autor poddaje szerszemu opisowi zależność między kapitalizmem a problemem zmian klimatu. Uznaje przy tym, że skuteczna walka ze zmianami klimatu możliwa jest wyłącznie poprzez redefinicję modelu kapitalistycznego. Stwierdza wprost, że problem klimatyczny będzie walką między niekontrolowanym kapitalizmem a planetą. Dlatego należy podjąć wysiłki, by „uratować kapitalizm przed nim samym”. Pewną nadzieję uczonego na przebudowę modelu kapitalistycznego zdaje się budzić podzielana nieufność wobec kapitalizmu zarówno po stronie socjalistów, jak i narodowców. Uczony zaznacza, że istnieje potrzeba modyfikacji kapitalizmu w taki sposób, aby w większym stopniu odpowiadał on na potrzeby całych społeczeństw, a w kontekście zmian klimatu - nawet całej ludzkości. Byłaby to z pewnością pożądana zmiana. Niestety, lecz w tym rozdziale pojawia się głównie krytyka zastanej rzeczywistości kapitalistycznej oraz pobieżny zarys negatywnych skutków globalizacji i deregulacji. Wiąże je on głównie $\mathrm{z}$ niesprawnością wielu państw i apetytem światowych elit w sprawie unikania podatków. Otwarcie też przyznaje, że warunkiem powodzenia jakiegokolwiek Green New Deal na świecie jest partycypacja elit w kosztach zielonej transformacji. To ultimatum jest dla niego ważne nie tylko ze względów finansowych, ale może nawet bardziej ze względu na potrzebę zapewnienia społecznej akceptacji dla wyrzeczeń, z którymi wiąże się niskoemisyjna transformacja. Lieven wskazuje w tym kontekście na przykład Francji, gdzie po zapowiedzi podniesienia opodatkowania na paliwo wybuchł protest tzw. żółtych kamizelek. Przykład ten jest może i trafny, ale moim zdaniem badacz nie dostrzega problemu 
równoległego, który stanowi jedną z przyczyn tego protestu. Jest on bowiem także skutkiem frustracji wielu zwykłych obywateli francuskich, wcześniej przekonywanych do zakupu mniej emisyjnych samochodów o napędzie wysokoprężnym. Po rozpropagowaniu sprzedaży tego rodzaju pojazdów elita polityczna zdecydowała się na krok kolejny, czyli propozycję obłożenia wyższym podatkiem właśnie tych użytkowników, którzy we wcześniejszych latach kupowali samochody promowane przez rząd. Wielu obywateli mogło więc uznać, że ich oszukano. Przywołany przykład w znacznie lepszy i szerszy sposób dotyka sedna problemu zarysowującego się między kapitalizmem i zmianami klimatu. Pokazuje on istotne znaczenie lobbingu i ciągłego kreowania popytu na pewne dobra materialne, których skutki środowiskowe okazują się niekiedy nie tak pozytywne, jak wcześniej zakładano. Koszty finansowe tych działań ponoszą najczęściej zwykli obywatele, którzy zastanawiają się nad rzeczywistymi intencjami prowadzenia polityki klimatycznej i tracą zaufanie do polityków nawołujących do postaw ekologicznych. Demokracje mają więc często największy problem z przewidywalnością i konsekwencją wprowadzanych przez siebie działań. Lieven słusznie odnosi się do tej kwestii, kiedy wskazuje na przykład Chin, gdzie biznes ma większą szansę zaadaptowania się do nowych zmian zarządzonych przez władzę centralną, których nie będą odwracały kolejne zmiany rządów. Argument ten jest z pewnością istotny i pozostaje tylko niedosyt, że badacz nie sięgnął tu po przykład UE, w której problem konsekwencji podejmowanych działań próbuje się rozwiązać przez odgórne nakładanie celów redukcji emisji na poszczególne państwa członkowskie. Powołując się w tym wątku na przykład UE, z pewnością znalazłby wiele dodatkowych argumentów wzbogacających niektóre tezy swojej książki. Z całą pewnością można jednak stwierdzić, że czwarty rozdział pozostawia spory niedosyt odnośnie do tego jak miałaby wygllądać, jego zdaniem, postulowana reforma kapitalizmu, aby w większym stopniu uwzględnił on koszty klimatyczne. Najlepszą puentą tej części publikacji pozostaje zawarty w niej cytat, zaczerpnięty z Lorda Nicholasa Sterna, który problem zmian klimatu uznał za największą zawodność rynku, z jaką świat miał kiedykolwiek do czynienia, i konieczna będzie bardzo znacząca ingerencja państwa oraz wola polityczna, aby to zmienić.

5 W wielu państwach członkowskich (w tym we Francji) pojazdy o silnikach wysokoprężnych należały do najchętniej nabywanych samochodów. 
Kwestię realizacji pożądanego w przekonaniu Livena Green New Deal podejmuje on w ostatnim rozdziale książki w połączeniu z narodową solidarnością. Wielki program społeczno-gospodarczej transformacji odwołuje się do amerykańskich doświadczeń w realizacji tzw. New Deal w latach trzydziestych XX w. Zdaniem autora, warunkiem powodzenia zielonej wersji New Deal jest wpisanie w niego priorytetu solidarności na poziomie państwa narodowego. Widać, że jego zamysłem było odwołanie się szczególnie do przypadku amerykańskiego, ǵdyż kreśli on sposoby skutecznego zaistnienia tematu Green New Deal w amerykańskiej kampanii prezydenckiej przed wyborami w 2020 roku. Uważa, że aby umieścić ten temat na samym szczycie agendy politycznej w Stanach Zjednoczonych, a jednocześnie pozyskać choćby część elektoratu Donalda Trumpa, Green New Deal powinien się stać programem narodowej transformacji przeprowadzanej w sposób solidarny. Choć należy zrozumieć intencje uczonego, który swoją książkę ewidentnie próbował wpisać w toczącą się amerykańską kampanię prezydencką i amerykański kontekst, to wydaje się, że praca Lievena mogłaby nawet zyskać na tym, gdyby podszedł on do opisywanej problematyki od początku do końca w bardziej globalnym ujęciu. Wiele stawianych tez, odnoszących się do amerykańskiego kontekstu, mogłoby okazać się słusznymi także w przypadku innych krajów, a waga postulowanych przez badacza rozwiązań nie ograniczała się tylko do Stanów Zjednoczonych. Oczywiście należy podkreślić, że działania USA są niezwykle istotne dla skuteczności globalnej walki ze zmianami klimatu. Nie dziwi więc, że osadził on problem relacji między zmianami klimatu a rolą państwa narodowego w kontekście amerykańskim. Zwłaszcza przed wyborami prezydenckimi w listopadzie 2020 roku, w których o reelekcję ubiegał się dotychczas urzędujący prezydent opowiadający się za wyjściem Stanów Zjednoczonych z Porozumienia paryskiego. Warto tym niemniej sięgnąć po omawianą książkę, przeczytać ją i przeanalizować z własnej (niekoniecznie amerykańskiej) perspektywy.

Konkludując swoje rozważania, brytyjski uczony wyraża przekonanie, że zachodni obywatelski patriotyzm powinien przenieść swoją aktywność z ekspansji liberalnej demokracji na rzecz jej obrony w państwach Zachodu, a etykę przekonań zamienić na etykę odpowiedzialności między zachodnimi elitami politycznymi. Autor stwierdza, że zachodnie próby budowy internacjonalistycznej wieży Babel poniosły fiasko, a w świecie istnieje narodowy wielogłos. Porażka państw zachodnich wynikała zaś przede wszystkim z ich niechęci do imitowania drogi państw Azji Wschodniej, 
które starały się kształtować globalizację pod kątem interesów własnych społeczeństw, nie rezyǵnując przy tym z ograniczeń w zakresie handlu i migracji. Na kartach samego zakończenia, jak i całej książki, rezonuje krytyka współczesnych elit politycznych państw zachodnich, które, cedując uprawnienia na inny poziom i odżegnując się od odpowiedzialności, tracą moralne prawo wymagania wyrzeczeń od zwykłych obywateli z powodu zagrożenia klimatycznego. Taka postawa elit i taki obrót spraw jest zdaniem uczonego zagrożeniem dla demokracji, dlatego należy próbować odbudować obywatelski konsensus w ramach państw narodowych. Co ciekawe, Lieven dostrzega również wagę przetrwania UE, ale stwierdza zarazem, że raczej w formie bliższej gaullistowskiej koncepcji Europe des Patries. Jednym z najbardziej doniosłych jego postulatów jest to, by społeczno-gospodarcza odnowa zachodnich demokracji stała się wzorem do naśladowania na świecie dla tych, którzy tego będą chcieli. Nie widać tu więc nawoływań do porównywalności wysiłków redukcyjnych podejmowanych przez różne państwa świata. Obraz świata, który rysuje nam na ostatnich kartach książki, to poliarchiczny system, w którym Zachód nie stanowi wzorcowego modelu dla innych i w pierwszej kolejności raczej sam powinien się w porę zatroszczyć o rozwiązywanie egzystencjalnego problemu, który może sprowadzić nieszczęście nie tylko na niego samego.

Prezentowanej książce z pewnością można sporo zarzucić. Stawiając sobie za cel zabranie głosu w debacie teoretycznej na gruncie stosunków międzynarodowych, badacz dość po macoszemu traktuje kwestię teorii. Słusznym diagnozom przyczyn brexitu, wzrostu populizmu, kosztów globalizacji czy potrzeby zredefiniowania kapitalizmu brakuje szerszego wymiaru i bardziej zniuansowanego spojrzenia na problemy, których skutki nie zawsze są podobne, nawet wyłącznie pośród państw zachodnich. Nie sposób jednak uniknąć wrażenia, że głównym celem książki było napisanie dość zwięzłego eseju i wywołanie nim potrzebnej na wielu poziomach dyskusji. Rozbudowanie wątku teoretycznego i większa objętość publikacji być może mogłyby wydać się zarówno autorowi, jak i wydawcy nieco kontrproduktywne w osiągnięciu tego celu. Mimo swoich mankamentów książkę Lievena należy uznać za ważny głos w debacie nie tylko klimatycznej, ale również teoretycznej (na gruncie stosunków międzynarodowych), politologicznej (szczególnie w kontekście dyskusji o roli państwa narodowego, przyczynach i konsekwencjach populizmu oraz skutkach globalizacji) czy ekonomicznej (w kontekście relacji kapitalizmu i zmian 
klimatycznych). Traktuje ona o fundamentalnych problemach współczesnego świata, szczególnie z perspektywy zachodniej, dlatego należy ją polecić szerokiemu gronu czytelników zainteresowanych toczącą się w świecie debatą. Powinna także być z uwagą analizowana w Polsce, ponieważ część tez postawionych przez uczonego rodzi istotne implikacje dla Polski.

Wydaje się, że szczególnie ciekawych refleksji nad prezentowaną książką dostarczyć może zestawienie jej z najgłośniejszymi tytułami amerykańskich politologów, filozofów i ekonomistów z ostatnich trzech dekad. Nie znaczy to, że dzieło Anatola Lievena zyska rozgłos na miarę pozycji, takich jak Koniec historii Francisa Fukuyamy ${ }^{6}, Z$ derzenie cywilizacji Samuela Huntingtona ${ }^{7}$, Potęga $i$ raj Roberta Kagana ${ }^{8}$ czy Paradoks globalizacji Daniego Rodrika ${ }^{9}$. Ma ono jednak - podobnie jak wszystkie wspomniane książki - tę cechę, że może być uznane za swoiste signum temporis szybko zmieniającej się epoki. Podobnie jak i prezentowana publikacja, mówiąc o rzeczach istotnych, opisują one rzeczywistość międzynarodową, osadzając ją w klimacie intelektualnym okresu, w którym powstały. Wiele spostrzeżeń w nich zawartych jest niezwykle cennych, część może budzić kontrowersje, całość jednak zbudowana została tak, aby pobudzić do myślenia, sprowokować debatę o rzeczach fundamentalnych i zakwestionować niektóre sposoby myślenia o polityce, ekonomii, kulturze, globalizacji, cywilizacji zachodniej czy państwie. Czytając książkę Lievena, po lekturach wcześniej wspomnianych głośnych pisarzy, jesteśmy w stanie dostrzec nie tylko rosnącą wagę zmian klimatu jako takiego, ale i w nie mniejszym stopniu zmianę klimatu intelektualnego, szczególnie w świecie zachodnim. Prezentowanej książce daleko bowiem do nastroju tryumfalizmu Zachodu, jaki wzbudzała lektura Końca historii. Tezy formułowane przez Lievena zdają się być równie odległe myśli neokonserwatywnej, która zakładała możliwość działania w sposób unilateralny i z wykorzystaniem

6 F. Fukuyama, Koniec historii i ostatni człowiek, tłum. T. Bieroń, M. Wichrowski, Wydawnictwo Znak, Kraków 2009.

7 S. P. Huntington, Zderzenie cywilizacji i nowy kształt ładu światowego, tłum. H. Jankowska, Muza, Warszawa 2003.

8 R. Kagan, Potęga i raj. Ameryka i Europa w nowym porządku świata, tłum. W. Turopolski, Wydawnictwo Studio EMKA, Warszawa 2003.

9 D. Rodrik, The globalization paradox. Why global markets, States, and democracy can't coexist, Oxford University Press, 2012. 
siły militarnej dla zapewnienia bezpieczeństwa amerykańskiemu hegemonowi. Jest więc nie mniej zdystansowany wobec zachodniego interwencjonizmu w imię krzewienia demokracji i dostrzega znacznie większą potrzebę jej obrony w zachodniej kolebce. Kładzie za to większy nacisk na potrzebę zredefiniowania kapitalizmu. A istniejące sprzeczności w ramach trylematu między globalizacją, demokracją i państwem narodowym na pewno nie postuluje przezwyciężać przez rezygnację czy osłabianie trzeciego z tych elementów. W tym kontekście można nawet wysnuć wniosek, że wielki nieobecny tej książki, którym jest wirus CoviD-19 ${ }^{10}$, mógłby nawet dostarczyć dodatkowych argumentów autorowi i wręcz wzmocnić przekaz oraz główne tezy książki. Mógłby on z powodzeniem stwierdzić, że wobec egzystencjalnych zagrożeń zarówno epidemicznych, jak i klimatycznych, państwo narodowe pozostaje niezmiennie głównym punktem odniesienia i oparcia obywateli, bo tylko ono dzięki swej legitymacji ma najistotniejsze prerogatywy $\mathrm{w}$ krytycznych sytuacjach do skutecznego działania.

Ci, którzy chcieliby odesłać państwo do lamusa historii, muszą więc nadal muszą więc nadal czekać.

10 Należy tu dodać, że z jak najbardziej zrozumiałych wzg̨lędów, książka bowiem ukazała się zanim jeszcze sytuacja epidemiczna, związana z wirusem coviD-19, przybrała skalę pandemii. 